\title{
Pemberdayaan Badan Eksekutif Mahasiswa Unu Ntb Sebagai Kader Penggerak Anti Kecurangan Pemilu
}

\author{
Hadi Wijaya \\ Dosen tetap Universitas Nahdlatul Ulama NTB \\ hadiwijaya.ntb@gmail.com
}

\begin{abstract}
Abstrak.
Badan Eksekutif Mahasiswa (BEM) UNU NTB merupakan sasaran peniliti untuk dijadikan sebagai kader penggerak anti kecurangan pemilu hai ini bertujuan untuk meningkatkan partisipasi masyarakat terhadap pemilu 2019 di Kota Mataram, ada beberapa alasan yang mendasari terciptanya judul tersebut. Pertama, sasaran komunitas yang dikenai program kami adalah BEM UNU NTB organisasi tersebut merupakan organisasi yang berada di bawah naungan Universitas Nahdlatul Ulama NTB. BEM UNU NTB ini memang sejak awal berdirinya fokus terhadap kegiatan- pengembangan kreativitas mahasiswa, Kependidikan dan keagamaan. Kedua, Dalam menjalankan Program kerja BEM UNU NTB acapkali mengembangkan kreatifitas mereka dengan prinsip swadaya, kebulatan tekad dan kesukarelaan. Maka dengan demikian, prinsip-prinsip tersebut menjadi modal untuk berbuat demi keberlangsungan organisasi dan mengabdikan diri dalam kegiatan kemasyarakatan. Metode penelitian yang digunakan adalah metode penelitian kualitaitf deskriptif. Hasil Penelitian menggambarkan bahwa Pemberdayaan BEM UNU NTB sangat tepat dilakukan karena berbagai factor yang mendukung di samping rasa kesukarelaan yang tinggi, idealisme yang tinggi dan dukungan dari masyarakat NU secara structural dan kultural juga menjadi pendukung berjalannya Program pemberdayaan ini.
\end{abstract}

\section{Kata Kunci: Pemberdayaan, BEM, Anti, Kecurangan, Pemilu}

\section{PENDAHULUAN}

Mahasiswa sebagai Agent social control memiliki tanggung jawab sebagai pengendali pelaksanaan demokrasi di Indonesia, Mahasiswa pada sebuah perguruan tinggi memiliki kelembagaan baim dari tingkat Program studi sampai dengan Universitas. Pada tingkat universitas kegiatan kemahasiswa dilaksanakan oleh Unit Kegiatan Mahasiswa (UKM) dan Badan Eksekutif Mahasiswa (BEM). Dalam konteks Demokrasi, Badan Eksekutif Mahasiswa merupaka perwujudan dari keterwakilan mahasiswa yang mendapatkan mandate untuk menjalankan program-program kemahasiswa yang mendukung visi-misi Universitas. Badan Eksekutif Mahasiswa tidak hanya memiliki tanggung jawab melaksanakan fungsi perubahan dan fungsi control di internal kampusnya saja namun memiliki tanggung jawab secara luas di tengah masyarakat. beberapa alasan lain yang mendasari terciptanya judul tersebut. Sasaran komunitas yang dikenai program kami adalah BEM Jurnal Ilmu Sosial dan Pendidikan
UNU NTB organisasi tersebut merupakan organisasi yang berada di bawah naungan Universitas Nahdlatul Ulama NTB. BEM UNU NTB ini memang sejak awal berdirinya fokus terhadap kegiatan- pengembangan kreativitas mahasiswa, Kependidikan dan keagamaan. Dalam menjalankan Program kerja BEM UNU NTB acapkali mengembangkan kreatifitas mereka dengan prinsip swadaya, kebulatan tekad dan kesukarelaan. Maka dengan demikian, prinsip-prinsip tersebut menjadi modal untuk berbuat demi keberlangsungan organisasi dan mengabdikan diri dalam kegiatan kemasyarakatan, untuk itu dianggap penting untuk melakukan sebuah kajian dan mengimplementasikan program pendidikan politik kepada mahasiswa khususnya pengurus BEM UNU NTB. Hal ini bertujuan agar pasca komunitas ini dididik paham akan bentuk-bentuk kecurangan dalam pemilu, serta mampu menelurkan pemahaman itu kepada lingkungan mereka. 
Oleh karena itu penulis menggangap penting untuk memberdayakan mahasisawa sebagai kader penggerak anti kecurangan pemilu untuk meningkatkan partisipasi masyarakat terhadap pemilu 2019 di Kota Mataram, ada

Sebagaimana yang telah ditegaskan dalam Konstitusi bahwa kedaulatan adalah di tangan rakyat. Melalui penyelenggaraan pemilu, baik presiden dan wakil presiden serta legislatif, harus dimaknai sebagai penyerahan mandat rakyat sebagai pemegang kedaulatan tertinggi. Oleh karena itu, penyelenggaraan pemilu tidak bisa dilepaskan dari peran publik, pemilih pemula dan warga negara. Bagaimanapun rakyat adalah pemilik kedaulatan sesungguhnya. Sebagai pemilik kedaulatan, berdasarkan kesepakatan bersama, rakyat memberikan kedaulatannya kepada penyelenggara negara.

Mengingat tingkat partisipasi pemilih khususnya di wilayah Kota Mataram pada pilkada sebelumnya menurun dibandingkan dengan partisipasi pemilih yang menyalurkan hak pilihnya pada saat Pilpres. dari data bahwa tingkat partisipasi masyarakat Kota Mataram, pada saat pemilihan presiden di tahun 2014 sebesar 70 persen jika dibandingkan dengan pilkada tahun 2015 hanya sebesar 55-60 persen dengan angka golput sebesar 133.756 suara namun saat pemilihan kepala daerah NTB pada tahun 2018 ada peningkatan $11,42 \%$ yaitu $71,02 \%$ tingkat partisipasif masyarakat dalam kontestasi PILKADA sementara tingkat angka golput $28,98 \%$ Dengan tingginya angka golput di Mataram, maka BEM UNU NTB sebagai organisasi keterpelajaran dan kemahasiswaan yang memiliki peran strategis dalam memahaman pengawasan pemilu dimasyarakat maka perlu dibentuk sekolah / pendidikan Kader Penggerak Demokrasi \& Anti Kecurangan Pemilu pada organisasi BEM UNU NTB sebagai bentuk tanggung jawab organisasi.

Bentuk partisipasi masyarakat dalam pemilu dapat diwujudkan, berupa:

1. Melaksanakan sosialisasi pemilu;

2. Melaksanakan pendidikan pemilih pemula;
3. Memilih calon atau pasangan calon partai politik dan membahas rencana visi, misi dan program partai dalam pemilu;

4. Memberikan suara sebagai pemilih pemula;

5. Menulis atau menyiarkan berita tentang pemilu;

6. Mendukung peserta pemilu/calon tertentu;

7. Mengorganisasi warga lain untuk mendukung atau menolak alternatif kebijakan publik yang diajukan peserta pemilu tertentu;

8. Menyampaikan hasil pemantauan atas pemilu dan menyampaikan pengaduan tentang dugaan pelanggaran pemilu;

9. Melakukan survey dan menyebarluaskan hasil survey tentang pendapat atau persepsi pemilih pemula tentang peserta pemilu/calon;

10. Melaksanakan dan menyebarluaskan hasil perhitungan cepat pemilu (quick count).

Pemetaan pelanggaran dan penekanan pada prioritas pencegahan akan memudahkan Bawaslu dalam mendorong pelibatan dan partisipasi pemilih pemula. Berdasarkan pemetaan tersebut, pengawasan pemilu dilakukan untuk pencegahan pelanggaran. Selain itu, pemetaan ini berguna sebagai sarana pendidikan pemilih pemula dan penyadaran kepada pemilih pemula lebih luas. Sehingga muncul kesadaran kritis masyarakat untuk turut serta mengawasi jalannya pemilu. Hasil pemetaan pelanggaran juga bisa dimanfaatkan untuk penyusunan instrumen pemantauan bersama sehingga pemantau, pemilih pemula, dan pemangku kepentingan lainnya bisa turut andil dalam memetakan persoalan.

Selain itu, fungsi pemetaan dan prioritas pengawasan bisa memudahkan Panwaslu dalam menyusun rencana strategis dan instrumen untuk mendorong partisipasi publik. Dengan demikian, Bawaslu bisa menentukan pelibatan masyarakat berdasarkan partisipan, informasi yang akan disampaikan, tata cara penyampaian, dan fasilitas/fasilitator yang akan mendukung penyampaian informasi yang efektif.

TUJUAN PENELITIAN 
Tujuan dari penulisan makalah ini antara lain:

1) Menjelaskan Konsep Pemberdayaan masyarakat

2) Menjelaskan kondisi Komunitas (BEM UN NTB)

3) Gambaran Kondisi Yang diharapkan

4) Menjelaskan faktor Kunci Keberhasilan

5) Langkah-langkah Pelaksanaan Program Pemberdayaan

\section{METODE PENELITIAN}

$\begin{array}{rcr}\text { Penelitian } & \text { ini } & \text { menggunakan } \\ \text { Pendekatan } & \text { kualitiatif } & \text { Deskriptif }\end{array}$

Menurut Sugiyono (2012:1) metode

penelitian

kualitatif adalah metode penelitian yang digunakan untuk meneliti pada kondisi obyek yang alamiah, dimana peneliti adalah sebagai instrumen kunci, teknik pengumpulan data dilakukan secara triangulasi (gabungan). Penelitian Deskriptif digunakan untuk melihat dan menggambarkan berbagai macam permaslahan yang sedang terjadi yang diungkapkan tanpa manipulasi. Pada penelitian ini peneliti mendiskripsikan bagaimana bentuk pemberdayaam BEM UNU NTB sebagai kader penggerak anti kecurangan pemilu.

\section{PEMBAHASAN}

\section{a. Konsep Pemberdayaan Masyarakat}

Istilah konsep berasal dari bahasa latin conceptum, artinya sesuatu yang dipahami. Konsep merupakan abstraksi suatu ide atau gambaran mental, yang dinyatakan dalam suatu kata atau symbol. Secara konseptual, pemberdayaan atau pemberkuasaan (empowerment), berasal dari kata power yang berarti kekuasaan atau keberdayaan. Konsep pemberdayaan berawal dari penguatan modal sosisl di masyarakat (kelompok) yang meliputi penguatan penguatan modal social (. Apabila kita sudah mem Kepercayaan (trusts), Patuh Aturan (role), dan Jaringan (networking))iliki modal social yang kuat maka kita akan mudah mengarahkan dan mengatur (direct) masyarakat serta mudah mentransfer knowledge kepada masyarakat. Dengan memiliki modal social yang kuat maka kita akan dapat menguatkan Knowledge, modal (money), dan people. Konsep ini mengandung arti bahwa konsep pemberdayaan masyarakat adalah Trasfer kekuasaan melalui penguatan modal social kelompok untuk menjadikan kelompok produktif untuk mencapai kesejahteraan social. Modal social yang kuat akan menjamin suistainable didalam membangun rasa kepercayaan di dalam masyarakat khususnya anggota kelompok (how to build thr trust). Oleh karena itu, ide utama pemberdayaan bersentuhan dengan konsep mengenai modal soaial dan kekuasaan. Kekuasaan seringkali dikaitkan dan dihubungkan dengan kemampuan individu untuk membuat individu melakukan apa yang diinginkan, terlepas dari keinginan dan minat mereka.Pada dasarnya, pemberdayaan dileta kkan pada kekuatan tingkat individu dan sosial (Sipahelut, 2010).

Pemberdayaan merujuk pada kemam puan orang, khususnya kelompok rentan dan lemah sehingga mereka memiliki kekuatan atau kemampuan dalam (a) memenuhi kebutuhan dasarnya sehingg a mereka memiliki kebebasan (freedom), d alam arti bukan saja bebas dalam mengem ukakan pendapat, melainkan bebas dari kel aparan, bebas dari kebodohan, bebas dari kesakitan; (b) menjangkau sumbersumber produktif yang memungkinkan mer eka dapat meningkatkan pendapatannya da $\mathrm{n}$ memperoleh barang-barang dan jasajasa yang mereka perlukan; dan (c) berpartisipasi dalam pros es pembangunan dan keputusan keputusan yang mempengaruhi mereka (Suharto 2005).

Pengembangan masyarakat tidak hanya sebatas teori tentang bagaimana mengembangkan daerah pedesaan tetapi memiliki arti yang kemungkinan perkembangan di tingkat masyarakat. Pembangunan masyarakat seharusnya mencerminkan tindakan masyarakat dan kesadaran atas identitas diri. Oleh karena itu, komitmen untuk pengembangan masyarakat harus mengenali keterkaitan antara individu dan masyarakat dimana mereka berada. Masyarakat adalah sebuah fenomena struktural dan bahwa sifat struktural 
dari kelompok atau masyarakat memiliki efek pada cara orang bertindak, merasa dan berpikir. Tapi ketika kita melihat struktur tersebut, mereka jelas tidak seperti kualitas fisik dari dunia luar. Mereka bergantung pada keteraturan reproduksi sosial, masyarakat yang hanya memiliki efek pada orang-orang sejauh struktur diproduksi dan direproduksi dalam apa yang orang lakukan. Oleh karena itu pengembangan masyarakat memiliki epistemologis logis dan yang dasar dalam kewajiban sosial yang individu memiliki terhadap masyarakat yang mengembangkan bakat mereka.

Adedokun,et all., (2010) menunjukkan bahwa komunikasi yang efektif akan menimbulkan partisipasi aktif dari anggota masyarakat dalam pengembangan masyarakat. Ia juga mengungkapkan bahwa ketika kelompok masyarakat yang terlibat dalam strategi komunikasi, membantu mereka mengambil kepemilikan inisiatif pembangunan masyarakat dari pada melihat diri mereka sebagai penerima manfaat pembangunan. Berdasarkan temuan tersebut, direkomendasikan bahwa para pemimpin masyarakat serta agen pengembangan masyarakat harus terlibat dalam komunikasi yang jelas sehingga dapat meminta partisipasi anggota masyarakat dalam isu-isu pembangunannya.

Konsep pemberdayaan menurut Friedman (1992) dalam hal ini pembangunan alternatif menekankan keutamaan politik melalui otonomi pengambilan keputusan untuk melindungi kepentingan rakyat yang berlandaskan pada sumberdaya pribadi, langsung melalui partisipasi, demokrasi dan pembelajaran sosial melalui pengamatan langsung. Konsep pemberdayaan menekankan bahwa orang memperoleh ketrampilan, pengetahuan, dan kekuasaan yang cukup untuk mempengaruhi kehidupannya dan kehidupan orang lain yang menjadi perhatiannya (Pearson et al, 1994 dalam Sukmaniar, 2007). Pemahaman mengenai konsep pemberdayaan tidak bisa dilepaskan dari pemahaman mengenai siklus pemberdayaan itu sendiri, karena pada hakikatnya pemberdayaan adalah sebuah usaha berkesinambungan untuk menempatkan masyarakat menjadi lebih proaktif dalam menentukan arah kemajuan dalam komunitasnya sendiri. Artinya program pemberdayaan tidak bisa hanya dilakukan dalam satu siklus saja dan berhenti pada suatu tahapan tertentu, akan tetapi harus terus berkesinambungan dan kualitasnya terus meningkat dari satu tahapan ke tahapan berikutnya (Mubarak, 2010).

Menurut Wilson (1996) terdapat 7 tahapan dalam siklus pemberdayaan masyarakat. Tahap pertama yaitu keinginan dari masyarakat sendiri untuk berubah menjadi lebih baik. Pada tahap kedua, masyarakat diharapkan mampu melepaskan halangan-halangan atau factorfaktor yang bersifat resistensi terhadap kemajuan dalam dirinya dan komunitasnya. Pada tahap ketiga, masyarakat diharapkan sudah menerima kebebasan tambahan dan merasa memiliki tanggung jawab dalam mengembangkan dirinya dan komunitasnya. Tahap keempat yaitu upaya untuk mengembangkan peran dan batas tanggung jawab yang lebih luas, hal ini juga terkait dengan minat dan motivasi untuk melakukan pekerjaan dengan lebih baik. Pada tahap kelima ini hasil-hasil nyata dari pemberdayaan mulai kelihatan, dimana peningkatan rasa memiliki yang lebih besar menghasilkan keluaran kinerja yang lebih baik. Pada tahap keenam telah terjadi perubahan perilaku dan kesan terhadap dirinya, dimana keberhasilan dalam peningkatan kinerja mampu meningkatkan perasaan psikologis di atas posisi sebelumnya. Pada tahap ketujuh masyarakat yang telah berhasil dalam memberdayakan dirinya, merasa tertantang untuk upaya yang lebih besar guna mendapatkan hasil yang lebih baik. Siklus pemberdayaan ini menggambarkan proses mengenai upaya individu dan komunitas untuk mengikuti perjalanan kearah prestasi dan kepuasan individu dan pekerjaan yang lebih tinggi.

Apabila kita cermati dari serangkaian literature tentang konsep-konsep Pemberdayaan Masyarakat maka konsep pemberdayaan adalah suatu proses yang 
diupayakan untuk melakukan perubahan. Pemberdayaan masyarakat memiliki makna memberi kekuatan/ daya kepada kumpulan masyarakat yang berada pada kondisi ketidakberdayaan agar menjadi berdaya dan mandiri serta memiliki kekuatan melalui proses dan tahapan yang sinergis.

\section{b. Gambaran Kondisi Komunitas}

Badan Eksekutif Mahasiswa (BEM ) UNU NTB merupakan organisasi kemahasiswaa intrakampus fokus terhadap jaringan pelajar, memiliki Pengurus sebanyak 20 orang dan seluruh mahasiswa UNU NTB menjadi anggota. BEM UNU NTB selama ini telah melaksanakan berbagai kegiatan baik dalam ruang lingkup Lokal maupun nasional salah satunya adalah Musyawarah Kerja Nasional (MUKERNAS IV) se Nusantara di Asrama Haji Kabupaten Lombok Barat tahun 2018. Identifikasi terhadap kelompok yang sadar politik cukup banyak dan beragam. Masing-masing kelompok ini memiliki kekuatan dan potensinya yang mesti diidentifikasi oleh Panwaslu. Identifikasi terhadap mereka akan memudahkan untuk melibatkannya dalam isu-isu spesifik yang sesuai dengan kompetensi masing-masing.

Beberapa kelompok yang mudah untuk diidentifikasi adalah pemantau pemilu, organisasi masyarakat sipil, universitas, organisasi kemasyarakatan dan kelompok lainnya seperti halnya BEM UNU NTB yang memiliki basis jelas. Keberadaan pemantau ini perlu dilibatkan secara maksimal oleh pengawas pemilu dan seyogyanya panwaslu dan atau bawaslu menggandeng dan memberi pelatihan kepada organisasi yang memiliki basis hingga akar rumput seperti halnya BEM UNU NTB yang memiliki basis hingga ke tingkat ranting

Kondisi yang sama juga dimiliki oleh BEM UNU NTB yang ada di universitas atau kampus. Paling tidak organisasi ini memiliki dua potensi yakni relawan dari mahasiswa dan sekaligus sebagai kelompok terdidik. Oleh karena itu yang perlu dilakukan oleh Panwaslu adalah mengidentifikasi potensi masing-masing kelompok.

Kelompok sadar politik yang diwakili oleh pemilih pemula yang mestinya menjadi mitra strategis Panwaslu untuk melakukan pendidikan pemilih pemula dan pengawasan. Kerja bersama Panwaslu dengan kelompok ini, akan memudahkan bagi Panwaslu dan atau bawaslu untuk menjangkau pemilih pemula lebih luas mengingat segi jumlah tentu pengawas pemilu yang hanya ditingkat kabupaten/kota tidak akan bisa menjangkau masyarakat dan pemilih pemula hingga TPS. Kelompok organisasi ini akan menyasar pemilih pemula dan kader kader inilah yang nantinya bekerja sebagai fasilitator-fasilitator yang menjembatani partisipasi masyarakat dalam pengawasan pemilu.

Untuk membentuk karakter BEM UNU NTB UNU NTB yang sadar demokrasi dan awas terhadap pelanggaran pelaksanaaan pemilu sebagai bentuk kepedulian terhadap demokrasi di tempat tinggal masing-masing kader maka Tujuan dibentuknya Kader Inti Penggerak Demokrasi Dan Anti Kecurangan Pemilu bertujuan untuk

a) Membantu pelaksanaan fungsi Panwaslu dan atau Bawaslu kota Mataram

b) Meningkatkan peran serta BEM UNU NTB dalam pengawasan partisipatif

c) Sarana pendidikan pemilu bagi BEM UNU NTB

d) Pembentukan pusat pendidikan pengawasan pemilu yang berkesinambungan bagi ipnu

e) Menciptakan kader inti penggerak demokrasi dan anti kecurangan pemilu

f) Menciptakan simpul pengawasan kecurangan pemilu di tingkat pelajar dan mahasiswa

Sasaran program ini adalah pelajar, remaja dan mahasiswa yang tergabung dalam organisasi BEM UNU NTB di masingmasing tingkatan yang di mulai dari tingkatan Pimpinan Cabang dan pimpinan komisariat pondok pesantren, pimpinan anak cabang,pimpinan ranting, pimpinan anak ranting Pimpinan Komisariat Perguuan Tinggi yang tersebar di 4 kampus yang nantinya dapat menyebarkan pemahaman anti kecurangan dalam pemilu pada masyarakat dan atau pemilih pemula sebagai bentuk partisipatif BEM UNU NTB dalam kontestasi pilkada maupun pemilu di tahun 2019. 
Pihak - pihak yang dilibat kan dalam hal ini adalah Panwaslu / Bawaslu kota Mataram sebagai kepanjangan tangan dari pemerintah

1. Alumni sekolah kader pengawasan partisipatif sebagai tutor dan fasilitator

2. Mahasiswa Universitas Nahdlatul Ulama NTB.

\section{c. Gambaran Kondisi Yang Diharapkan}

Komunitas yang akan menjadi sasaran untuk melaksanakan program pendidikan pemilu adalah BEM UNU NTB. Peneliti tertarik dan tertantang untuk belajar bersama dengan BEM UNU NTB dalam mewujudkan partisipasi masyarakat terhadap pemilu. Organisasi ini termasuk wadah pelajar, santri, mahasiswa dan pemuda di semua tingkatan mulai dari tingkat kota hingga ranting yang memang fokus dengan kegiatan sosial keagamaan dan keterpelajaran serta kemasyarakatan.

Komunitas atau organisasi ini bisa dikatakan belum lama berdiri yakni seusia kampus UNU NTB yang baru lima tahun. Akan tetapi, BEM UNU NTB terlahir dari tubuh NU yang memiliki jejaring masyarkat yang begitu luas, sehingga menjadikan memudahkan untuk melaksanakan kegiatan di tengah masyarakat.

Struktur organisasi BEM UNU NTB dibentuk mulai dari jajaran pembina, penasehat pengurus harian hingga ke anggota perwilayah. Pembina adalah Wakil Rektor III UNU NTB

BEM UNU NTB muncul bukan hanya sekadar tempat berhimpun mahasiswa saja pelajar namun mereka juga memiliki arah dan tujuan fokus terhadap kegiatan sosial kegamaan dan keterpelajaran sehingga program kerja di masing masing tingkatan terlihat massif dan aktif nah dengan keunggulan seperti ini menurut penulis perlu menggandeng ipnu sebagai sarana pendidikan kader inti penggerak anti kecurangan pemilu di setiap kecamatan dan kelurahan.

Uraian fakta aktual yang terjadi di kecamatan sekarbela kota mataram akan menjadi sebuah pembelajaran dan bahan evaluasi buat kita. Karena sejak awal kita telah bertekad untuk memegang teguh nilai demokrasi itu. Misal kejadian saat pilgub NTB tahun 2018 di kecamatan sekarbela terjadi pelanggaran dengan hilangnya 1surat suara pasca penghitungan. Dan ada juga menurut seseorang warga mendapatkan serangan fajar. Dengan demikian setelah program pendidikan kader inti penggerak anti kecurangan pemilu ini, masyarakat khususnya anggota BEM UNU NTB akan paham bagaimana pentingnya menjaga asas demokrasi itu dan mengawasi pelaksanaan pemilu di tempatnya masing-masing hingga demokrasi lebih baik. Sehingga pemilu 2019 ini tidak akan terjadi lagi intimidasi pemilih, money politik dan. Kecurangan kecurangan yang dapat merugikan semua kalangan

Kemudian jika pengalaman Pilgub NTB 2018 dan pemilu 2014 masih ada praktik money politic, intimidasi, dan diskriminasi kota Mataram, maka setelah BEM UNU NTB paham tentang kecurangan kecurangan yang saat terjadi dalam pelaksanaan baik pra saat maupun setelah pemilu, masyarakat sekitar tempat tinggalnya juga diharapkan akan ikut cerdas dalam menentukan pemimpinnya. Selain itu juga BEM UNU NTB diharapkan dapat meningkatkan partisipasi masyarakat dalam pemilu, dan praktik demokrasi di daerah tersebut akan semakin baik.

\section{c. Faktor Kunci Keberhasilan}

Dalam menentukan berhasil atau tidaknya suatu kegiatan maka diperlukan faktor kunci keberhasila program atau kegiatan yang akan dilaksanakan menurut penulis langkah atau fator yang dapat membawa keberhasilan program ialah :

- semangat dan jiwa sukarela dan militansi sangat tinggi terhadap pimpinan ( Tuan Guru)

- Pengurus dan anggota terdiri darimahasiswa yang masih berpikir idealis dan kritis

- Berkoordinasi kepada bawaslu sebagai perpanjang tanganan pemerintah

- Berkoordnasi dengan ketua cabang dalam melaksanakan kegiatan

- Berkoordinasi dengan LPSK provinsi

- Menyusun kurikulum dan metode yang digunakan dalam pelaksanaan pendidikan kader inti 
- Mengevaluasi dan menindak lanjuti hasil kaderisasi BEM UNU NTB

\section{d. Langkah-langkah Program Pemberdayaan}

Pelaksanaan

Untuk mencapai keberhasilan program

ini, maka harus diperhatikan beberapa

langkah-langkah berikut ini :

\section{Langkah 1 :}

Sebelum penulis terjun langsung kepada BEM UNU NTB, hal pertama yang dilakukan adalah membuka akses ke semua pihak, yakni BAWASLU Kab, PANWASCAM, KPU Kota Mataram, , pembina ipnu, dan ketua Selanjutnya peneliti mensosialisasikan dan berkonsultasi kepada pihak yang terkait. Komponen tersebut dirasa urgen untuk membantu memperlancar program ini.

\section{Langkah 2 :}

Menyusun materi pendidikan pemilu yang akan dikaji. Banyak bahan ajar yang menunjang pemahaman kader inti penggerak anti kecurangan pemilu. Namun penulis hanya membatasi beberapa materi penting menghadapi pemilu 2019.

\section{Langkah 3 :}

Selanjutnya materi yang telah ditentukan menjadi modul pendidikan pemilu untuk kader penggerak anti kecurangan pemilu. Sehingga dirasa penting modul tersebut menjadi pegangan untuk mereka. Buku ajar tentang pemilu suatu saat akan berguna bagi organisasi BEM UNU NTB , jikalau penyampaianya oleh fasilitator kurang terserap. Maka kemudian, sebelum pendidikan pemilu ini dilaksanakan, penggandaan modul harus siap terlebih dahulu.

\section{Langkah 4 :}

Menentukan tempat strategis yang akan dibuat untuk pendidikan pemilu.. Tempat tersebut adalah aman dari gangguan pihak luar, nyaman, dan mudah dijangkau.

\section{Langkah 5 :}

Menentukan fasilitator pada pendidikan pemilu. Pada tahap ini juga penting diperhatikan, mengingat target pemahaman Kipaku terhadap kerawanan. Sehingga untuk turun lapangan ke masyarakat tidak salah konsep. Maka perlu menghadirkan fasilatator-fasilatator yang mumpuni sesuai dengan materi dalam modul.

\section{Langkah 6 :}

Mapping area di setiap kecamatan yang tingkat partisipasi masyarakat terhadap pemilu masih rendah dan tingkat kerawanan masih tinggi..

\section{Langkah 7 :}

Menjalankan pendidikan pemilu di mulai dari bulan Agustus hingga 6 bulan ke depan. Pelaksanaan program ini yang harus diperhatikan adalah kesiapan anggota BEM UNU NTB mengikuti pendidikan, kesepakatan waktu pelaksanaan, dan kejelasan yang akan menjadi fasilitator. Dengan demikian, program pendidikan pemilu berjalan dengan efektif dan maksimal.

\section{Langkah 8 :}

Melakukan monitoring dan evaluasi setelah turun lapangan ke masyarakat dititik titik yang sudah ditentukan. Evaluasi ini berguna untuk mengetahui dan memberikan solusi terhadap segala kekurangan serta kendala yang terjadi saat turun lapangan di masyarakat.

\section{Langkah 9 :}

Pemantapan pengawasan partisipatif masyarakat menuju pemilu 2019. Hasil pendidikan kader inti selanjutnya akan lebih difokuskan kepada pelaksanaan pemilu 2019. Teknis partisipasi masyarakat bisa melalui pengawasan langsung (pra dan proses pemilu), melaporkan kepada panwas dan bawaslu jika terjadi pelanggaran, mengajak semua unsur masyarakat yang memiliki hak pilih untuk ke TPS, dan mengawal hingga hasil rekapitulasi suara selesai.

\section{KESIMPULAN}

Dengan adanya pendidikan kader penggerak anti kecurangan pemilu ini diharapkan dapat membantu bawaslu dalam pelibatan masyarakat secara massif melalui simpul simpul yang sudah dibangun oleh 
bawaslu. Sehingga menjadikan pemilu kedepan lebih baik dari yang diharapkan dengan pengawasan partisipatif dari BEM UNU NTB yang nantinya dapat menyebarkan virus virus kebaikan melalui partisipatif masyarakat kepada masyarakat umum

SARAN

Penulis berharap penyelenggaraan pemilu 2019 berjalan dengan efektif dan minim sengketa dengan terlibatnya kipaku sebagai simbol partisipatif masyarakat. Sehingga hal ini perlu adanya kolaborasi antara semua pihak pendukung yakni penyelengara, TNI/POLRI, ASN, partisipasi masyarakat. Pada pemilu 2019 tidak akan lagi ada saling menyalahkan baik antar penyelenggara dan penyelenggara, penyelenggara dan masyarakat, penyelenggara dan peserta pemilu.

\section{DAFTAR PUSTAKA}

Friedman, D., \& McAdam, D. (1992). Collective identity and activism: Networks, choices, and the life of a social movement. In A. D. Morris \& C. M. Mueller (Eds.)

International IDEA, International Electoral Standards, Guidelines for Reviewing the Legal Framework of Elections, 2002)

http://rri.co.id/post/berita/389238/daerah/ntb_ urutan_kedua_nasional_hasil_peme taan indeks_kerawanan pemilu.ht ml (Diakses 2 Februari)

http://sosial-keagamaan.kampungmedia.com/2018/04/23/formudatastura-gelar-diskusi-wisata-halal23801. (Diakses 5 Februari)

https://prasfapet.wordpress.com/2015/05/07/k onsep-dan-teori-pemberdayaanmasyarakat/ (Diakses 7 Januari)

Muhammad AS Hikam. Demokrasi dan Civil Society. Jakarta: Pustaka 1999.

Undang-undang Pemilu Nomor 7 Tahun 2017

Peraturan Bawaslu Nomor 15 Tahun 2015 Tentang Rencana Strategis Badan Pengawas Pemilu Tahun 2015$\underline{2019}$

Ramlan Surbakti, Memahami Ilmu Politik. Jakarta: Grasindo, 2010
Sofyan S Harahap, Analisa Kritis Atas Laporan Keuangan. Jakarta: Raja Grafindo Persada, 2001

Sipahelut, $\quad$ Michael. 2010. Analisis Pemberdayaan Masyarakat Nelayan di. Kecamatan Tobelo Kabupaten Halmahera Utara. Jurnal Institut Pertanian. Bogor.

Suharto, Edi. membangun masyarakat memberdayakan rakyat, bandung:Refika. Aditama, 2005.

Wilson, P.A. (1995) Embracing locality in local economic development, Urban Studies, 32, pp. 645-658 